\title{
Sumarni pregled objavljenih radova u časopisu Sociologija sela u razdoblju 1976. - 1986. godine za vrijeme uredništva Ruže First-Dilić
}

\author{
Milan Župančić \\ Institut za društvena istraživanja u Zagrebu (u mirovini), Hrvatska
}

U drugoj polovini 1970-ih časopis nastavlja s tematskim inovacijama, sadržajnim obogaćivanjem i proširenjem kruga suradnika. To širenje ide u dvama pravcima: pionirsko ,jezgro“ suradnika locirano na transverzali Ljubljana-Zagreb-Beograd biva dopunjavano i obogaćivano nizom vrijednih istraživača iz drugih sredina, kao što su Novi Sad, Sarajevo, Skoplje, ali i manje sredine. S druge strane, svojim prilozima i istraživačkim rezultatima časopisu se priključuju mnogi mlađi i neafirmirani autori što svakako doprinosi podizanju razine kvalitete i bogatijem profilu časopisa. U tom razdoblju osjeća se i više „sociologiziranosti“ u pristupu i načinu obrade pojedinih tema, strože metodološke fundiranosti pojedinih istraživanja i eksplikacije rezultata, kao i izvjestan odmak od klasičnog ekonomističkog pristupa u bavljenju agrarnim i poljoprivrednim temama. Naprosto veća i raznovrsnija ponuda i povećan broj suradnika doprinio je bogatijoj i raznovrsnijoj „ponudi“ materijala za objavljivanje. To je i posljedica ranijih napora uredništva i glavnog urednika Vlade Puljiza za suvremenijim profiliranjem časopisa.

Postupnim udaljavanjem (zbog preorijentacije na fakultetsku karijeru) i odlaskom V. Puljiza iz Instituta 1976. godine nova glavna urednica časopisa postaje R. First-Dilić. Ustalila se i donekle je proširena rubriciranost na tematske cjeline kao što su: noseći članci, rasprave, informacije o različitim istraživanjima u svijetu, prijevodi važnijih i teorijski relevantnih problema u svjetskoj literaturi iz ruralnosociologijske domene, aktualne teme i rasprave, prilozi iz naše ruralne prošlosti, a posebno su njegovani prikazi knjiga i časopisa od interesa za istraživačku djelatnost grupe za sociologiju sela, proširenu i na sociologiju prostora.

Već u broju 52-53 iz 1976. nailazimo na interesantne priloge proizašle iz istraživanja metropolitanizacije zagrebačke regije i onih procesa koji prožimaju i transformiraju ruralna naselja u toj regiji i šire u Središnjoj Hrvatskoj. Tu se došlo do empirijskih verifikacija onog što se u američkoj sociologiji zvalo teorija rural-urban kontinuuma, dakle svi oni utjecaji i međusobna isprepletenost šireg prostora i postupnog smanjivanja velikih razlika u životu seoskih područja naspram „čisto“ urbaniziranih zona. 
Naravno, u okviru skromnih dometa u urbaniziranosti tadašnjeg društva i specifičnosti tadašnjeg sistema. U tom tematskom bloku vrijedno je spomenuti radove R. First-Dilić, I. Cifrića, I. Magdalenića i D. Seferagić. Vrijedno je zabilježiti da su u tom broju objavljena i dva priloga o zdravstvenom osiguranju poljoprivrednika i pomalo futuristički intonirani radovi L. Antića i F. Kamenečkog o mogućnostima uvođenja mirovinskog osiguranja za seljake (tada smo još imali blizu 30\% seljačkog stanovništva, dakle, četiri do pet puta više no danas).

Sljedeći broj časopisa iz iste godine posvećen je problematici inovacija u poljoprivredi i seoskom životu. Uloženi su veliki napori da se osvijetle mnogobrojne posljedice uzmicanja i nestanka tradicionalnih formi rada i poslovanja u seljačkoj poljoprivredi, kao i uvođenja suvremenijih sadržaja u potrošnji, stanovanju i opremljenosti seoskih domaćinstava. Uz posvetu preminulom Vojislavu Đuriću, jednom od naših glavnih suradnika iz Novog Sada, tiskan je i njegov kapitalni rad iz teorije difuzije inovacija, što je i bila njegova bazična preokupacija. Objavljen je i niz radova iz mnogih poljoprivrednih oblasti (kemizacije poljoprivrede, stočarstva, uvođenja pojedinih kultura u poljoprivredu). Interesantan je i pokušaj M. Župančića da rasvijetli širi sklop historijskih okolnosti uvođenja novih poljoprivrednih kultura i postupaka u našu poljoprivredu.

U sljedećoj godini objavljeni su brojevi 55-56, 57 i 58 s mnoštvom zanimljivih priloga. Udarna tema broja 55-56 starenje je seoske, napose poljoprivredne populacije i posljedice senilizacije u poljoprivredi na ekonomski i socijalni položaj seljaštva i perspektive daljeg razvoja sela. Tangirani su različiti aspekti tih procesa, a posebno valja istaći priloge E. Dilića Psihološka prilagođenost starenju u selu i članak S. Livade Staračka gospodarstva i podruštvljavanje.

Sljedeći broj časopisa (57) detaljnije se bavi mogućnostima uvođenja mirovinskog osiguranja poljoprivrednika u Hrvatskoj. Iako se za tadašnje prilike ta mogućnost činila utopijskom, vrijedilo je barem teorijski skicirati konture budućeg mirovinskog osiguranja seljaka, čime je započela i senzibilizacija šire javnosti za probleme ostarjelih generacija seoske populacije. U nekoliko napisa detaljno su razrađeni elementi buduće strategije rješavanja tog problema. Dane su projekcije kretanja broja individualnih poljoprivrednih gospodarstva i seljačkog stanovništva do kraja 2000. godine (usput rečeno, projekcije su se pokazale prilično točnima, naročito u svjetlu daljnjeg ubrzanja procesa deagrarizacije koji je u tom periodu i inače bio dramatski buran). Seljaštvo je u tom i narednom razdoblju naprosto „kopnjelo“, što su autori analitički obrazložili i kvantificirali. Mogući scenariji o načinima i izvorima financiranja ukazali su samo na okvirne veličine, koje su kasnije mijenjane i modificirane. Od interesantnijih i značajnijih članaka u tom kompleksu izdvajamo onaj V. Puljiza i R. First-Dilić Stavovi poljoprivrednika o načinu osiguranja u starosti i prilog S. Livade Neka rješenja umirovljenja poljoprivrednika.

U narednom broju aktualna je tema obrazovanje poljoprivrednika i tu nalazimo na niz značajnih priloga o važnosti obrazovanja poljoprivrednika u daljnjem razvoju moderne i efikasnije poljoprivrede i njenom uklapanju u društvenu podjelu rada. 
Ukazujemo pritom na fundiran doprinos M. Štambuk naslovljen kao Stavovi o potrebi stručnog obrazovanja poljoprivrednika te na komplementaran članak M. Stojanova Profesionalizacija rada u poljoprivredi.

I u 1978. godini nastavljen je intenzivan ritam prezentacije aktualnih ali i teorijski relevantnih tema. U prvom broju iz te godine ukazujemo na članak J. Defilippisa Proizvodno-ekonomska obilježja poljoprivrednih i mješovitih domaćinstava u SR Hrvatskoj. Vrijedi podsjetiti i na koherentan prilog o vrednotama u poljoprivredi pod naslovom Vrijednosne orijentacije i politika u odnosu na poljoprivrednu proizvodnju, autor kojega je D. Sekulić.

Zadnji broj iz 1978. godine sadržava vrlo aktualnu temu o komasaciji zemljišta, naročito zbog enormne usitnjenosti i rasparceliranosti zemljišta individualnog sektora, koje su i najveće zapreke efikasnijem korištenju moderne agrotehnike i postizanju boljih ekonomskih rezultata u seljačkoj poljoprivredi.

U 1979. godini osjeća se pomak na novu i dosada zanemarenu društvenu problematiku, a to je položaj seoske žene. U nizu članaka teorijskog karaktera zahvaćene su brojne dimenzije „ženskog pitanja“, naročito one koje dotiču promjene u seoskoj porodici, činjenicu većeg angažiranja seoske žene na poljoprivrednom gospodarstvu ili u drugim djelatnostima, usklađivanje tih novih obaveza seoske žene s tradicionalnim ulogama žene kao što su rad u domaćinstvu, briga za djecu i funkcioniranje seoske porodice. Istaknuta je i teza da zbog zapošljavanja muških članova domaćinstva izvan poljoprivrede sve veći dio poslova otpada na seosku ženu, a da u selu nema potrebnih servisa koji bi je mogli rasteretiti od dijela obaveza i poslova u domaćinstvu. Zbog evidentne feminizacije, tj. povećanog angažmana žena u poljoprivredi, uz zadržane obaveze i opterećenja tradicionalnog karaktera, položaj je seoske žene čak i pogoršan naspram nekadašnjem stanju. Ovo je svakako važan zaključak jer govori da su seoske žene dale velik doprinos u cjelokupnom razvoju i društvenom napretku seoskih područja. D. Štampar je u tom sklopu priložila svoj članak Planiranje obitelji na seoskom i gradskom području SR Hrvatske i time zakoračila i u tu važnu sferu obiteljske problematike glede planiranja veličine seoske porodice.

U toj godini nailazimo na radove posvećene podruštvljavanju poljoprivrede koji su ispunili gotovo cjelokupan broj 65-66. Iako se iz današnje perspektive čini da je to ideologizirana tema, to je ipak površni utisak jer su prikazani i problematizirani mnogi faktori koji upućuju na potrebu povezivanja individualnih gospodarstava $s$ organizacijama društvenog sektora, integracije seljaka u šire asocijacije, zadrugarstva, što je sve vodilo u pravcu napretka sela i lakšeg uključivanja u suvremene društvene tokove. V. Cvjetićanin i V. Puljiz znalački problematiziraju taj kompleks u članku Faktori promjena u individualnoj poljoprivredi i udruživanje poljoprivrednika, a M. Župančić je autor rada Podruštvljavanje poljoprivrede u marksističkoj teoriji društvenog razvoja.

U 1980. nastavljen je trend objavljivanja aktualnih materijala, iako je bilo i nekih slabijih i „tanjih“ izdanja. To se u prvom redu odnosi na broj 67-68 u kojem su pre- 
zentirani radovi o političkim organizacijama (djelovanje Saveza komunista u selu i slično), razglabanja i neka prigodna zapažanja o poljoprivredi vodećih državnih funkcionera, kao i druge ideologizirane teme.

Sljedeći se broj vraća ustaljenoj praksi objavljivanja znanstveno relevantnih sadržaja. Tako E. Dilić člankom Motivacije za bavljenje dvojnom aktivnošću osvjetljava fenomen mješovitih domaćinstava/gospodarstava kao jedan od najznačajnijih problema ruralne sociologije. Autor se, s osloncem na provedeno istraživanje mješovitih gospodarstava provedenom u svim jugoslavenskim sredinama, fokusira na čitav splet faktora od opće razvijenosti seoskih sredina, postojeće agrarne strukture i rascjepkanosti seljačkog posjeda do preferencija i aspiracija mlađih generacija u selu te dolazi do zaključka o relativnoj trajnosti i ukorijenjenosti mješovite poljoprivrede u seoskoj strukturi. Meni se čini da je to aktualno i danas, o čemu bi trebali voditi računa i kreatori agrarne politike jer isključivo preferiranje većih i tržišno usmjerenih gospodarstava dovodi do imobilizacije mnogih potencijala u seoskoj privredi.

U narednoj godini tematski fokus proširen je na neke sociokulturne fenomene koji su dosada bili zanemarivani. Tako A. Hodžić objavljuje članak Individualizam $i$ kooperativizam seljaštva u kojem razglaba jedan od vječnih i nerješivih sporova u sociologiji i kulturnoj antropologiji o „biću“ seljaka - koliko je on zbog samodovoljnosti i relativne autonomije u široj društvenoj mreži sklon individualizmu ili je, pak, spreman na kooperativnije ponašanje i participaciju u društvenim poslovima. Autor daje produbljeniju analizu tog problemskog čvora i zaključuje kako koristi seljaka u funkcionalnoj sferi postupno nagrizaju tradicijske obrasce ponašanja i približavanju ga participativnijem modelu inkluzije u šire kolektivne aranžmane. U istom svesku časopisa M. Golob prilaže članak naslovljen O promjenama u sistemu vrijednosti seljaka Slovenije i zapaža neke slične tendencije vrijednosnih promjena na slovenskom tlu.

Zanimljiv je i prilog Lj. Plačka o rasprostranjenosti religije u ruralnom ambijentu i nekim razlikama prema religioznosti u gradskim sredinama.

Sljedeći svezak donosi niz intrigantnih napisa iz šire palete ruralnosociologijske misli. R. First s dosta akribije razglaba o shvaćanju pojma ruralnosti jer je očigledno da se on ne odnosi samo na život u selu, već i mnogi drugi vidovi prisutnosti (vikendaši, seoski turizam, kao i srodničke i zavičajne klike seoskog porijekla u gradu) imaju itekakve veze s ruralnošću. D. Sergejev u svom prilogu Velika preobrazba grada djelomice potvrđuje takva shvaćanja, iako i gradski život prolazi burne transformacije uvjetovane novim stilovima života.

Naredno godište više je u znaku povratka klasičnim agrarnim i seljačkim temama. V. Radomirović opisuje i analizira faktore reprodukcije u poljoprivredi, s posebnim osvrtom na kapital i radnu snagu koja zbog senilizacije i feminizacije sve više postaje ograničavajući resurs u seljačkoj poljoprivredi. J. Tavčar objavljuje prilog Individualni sektor u slovenskoj poljoprivredi u kojem ukazuje na razloge koji dovode do veće efikasnosti slovenske poljoprivrede u odnosu na druge sredine. Vrlo korisnu informaciju o stanju u razvijenom ambijentu agrarno bogate sredine podastire V. Puljiz 
u prilogu o organizacijskim formama u poljoprivredi širom Europe. Tu se vidi da i u razvijenim zemljama postoji razgranato zadrugarstvo i posebne forme vertikalne integracije u poljoprivredi, što olakšava poslovanje poljoprivrednih gospodarstava a farmerima donosi sigurnost i viši dohodak.

Sljedeći brojevi usmjereni su više na demografske teme, promjene u strukturi stanovništva i depopulacijske procese u seoskom prostoru. M. Štambuk je autorica preglednog članka o promjenama u sociodemografskoj strukturi seoskog stanovništva; V. Puljiz upozorava na nove trendove deagrarizacije; objavljuju se napisi o depopulacijskim procesima a ima i upozoravajućih radova o lošim posljedicama deagrarizacije i deruralizacije na većinu seoskih područja. S. Livada u svom članku Vitalni pokazatelji o seoskom i poljoprivrednom stanovništvu SR Hrvatske ili demografski slom, pomalo katastrofičarski intoniranom, upozorava da će dugoročni nepovoljni trendovi napuštanja sela imati trajne posljedice na mogućnosti ravnomjernog razvoja pojedinih regija i harmonični napredak ukupnog društva, što se i obistinilo u suvremenom razdoblju, ali će se izvjesno osjećati i u budućnosti. Mnoga ruralna područja dugoročno su osuđena na kaskanje i zaostajanje za razvijenijim sredinama što ce imati brojne negativne društvene i političke posljedice na širem planu.

Trobroj 83-86 iz 1984. godine donosi „smirenije“ radove šireg spektra, a valja izdvojiti napis M. Oliveire Roca o tipovima migracija na jugoslavenskom prostoru, N. Kerovec o neformalnom radu u našoj ekonomiji te napis o zdravstveno-ekološkim aspektima stanovanja u selu, napisan od veće grupe autora. O. Grgurević je autor empirijski izvrsno fundiranog napisa Funkcionalno-morfološka struktura suburbanog prostora, a taj prostor povezuje ruralnu i urbanu sociologiju i ukazuje na njihovu isprepletenost u nastojanju da potpunije objasne prirodu suvremenih promjena u prostoru.

Četverobroj 87-90 donosi rezultate istraživanja o društvenom položaju Roma, jedne marginalne skupine koja je po svim pokazateljima na dnu društvene ljestvice. To se vidi po njihovoj ekonomskoj, društvenoj i kulturnoj marginalizaciji. Donedavno nisu imali nikakav pravno-politički status jer nisu ni nacionalna manjina o kojoj bi se „brinula“ matična država. Rezultati istraživanja ukazuju na krajnje nepovoljan životni standard izražen u vrlo siromašnom stambenom fondu, slaboj opremljenosti kućanstava suvremenom opremom, neurbaniziranim naseljima i sl. Posebno su izraženi problemi u školovanju djece, zapošljavanju i uključenosti u društveni život u sredinama gdje žive. Vrlo su snažne društvene predrasude većinskog stanovništva prema Romima, a izloženi su diskriminaciji u mnogim životnim situacijama. Poboljšanja su moguća, ali iziskuju dugoročne napore društva da omogući obrazovanje mlađim generacijama, olakša zapošljavanje radnom kontingentu Roma i kulturno podizanje cjelokupne romske populacije. Treba inzistirati i na većoj društvenoj podršci u smanjivanju i postupnom uklanjanju negativnih predrasuda prema toj ranjivoj društvenoj skupini.

Svezak 24 časopisa s brojevima 91-94 posvećen je demografskim kretanjima u reprodukciji stanovništva Hrvatske. Niz eminentnih autora i istraživača zahvatilo je širok tematski repertoar o prošlosti i budućnosti razvoja stanovništva i populacijskoj 
politici potrebnoj za zaustavljanje negativnih trendova, zabrinjavajućih već tada, koji su do danas poprimili katastrofične dimenzije. Nažalost, demografski problemi nisu kod nas nikad ozbiljno shvaćani u promišljanjima dugoročnog razvoja niti su bili u fokusu pažnje odgovornih političkih faktora. Posljedice toga osjećamo danas, a u budućnosti bit će još izraženije. Odgovornost za to ponajmanje leži u znanstvenim redovima, istraživačkim interesima i preokupacijama, o čemu zorno svjedoče i objavljeni radovi u našem časopisu. 